\title{
EWS/FLI 1 Type 4
}

National Cancer Institute

\section{Source}

National Cancer Institute. EWS/FLI 1 Type 4. NCI Thesaurus. Code C29024.

The type 4 form of EWS/FLI-1, an oncogenic fusion gene found in Ewing 's sarcoma and primitive neuro-ectodermal tumor (PNET). Resulting from a t $(11 ; 22)$ chromosomal translocation, EWS/FLI 1 appears to play an integral role in the development of Ewing's sarcoma and PNET; the type 4 form of this gene has been shown to transform nonneoplastic cells. EWS/FLI 1 type 4 represents a potential target for antisense oligonucleotide therapy of Ewing's sarcoma and PNET. (NCI04) 